Canadian Journal of Civil Engineering

Canadian

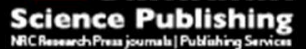

Revue canadienne de génie civil

\title{
EVALUATION OF GOVERNING PARAMETERS ON PIER SCOUR GEOMETRY
}

\begin{tabular}{|r|l|}
\hline Journal: & Canadian Journal of Civil Engineering \\
\hline Manuscript ID & cjce-2016-0133.R1 \\
\hline Manuscript Type: & Article \\
\hline Complete List of Authors: & $\begin{array}{l}\text { Williams, Priscilla; University of Windsor, Department of Civil and } \\
\text { Environmental Engineering } \\
\text { Bolisetti, Tirupati; University of Windsor, Department of Civil and } \\
\text { Environmental Engineering } \\
\text { Balachandar, Ram; University of Windsor, Civil and Environmental } \\
\text { Engineering }\end{array}$ \\
\hline Keyword: & erosion and sediment < Hydrotechnical Eng., Bridge pier scour \\
\hline & \\
\hline
\end{tabular}

SCHOLARONE ${ }^{\text {m }}$

Manuscripts 


\title{
EVALUATION OF GOVERNING PARAMETERS ON PIER SCOUR GEOMETRY
}

\author{
Priscilla Williams, EIT, Tirupati Bolisetti, P.Eng., and Ram Balachandar, P.Eng. \\ Department of Civil and Environmental Engineering \\ University of Windsor, Windsor, ON, Canada
}

Corresponding Author:

Dr. Tirupati Bolisetti

University of Windsor

Dept. of Civil and Environmental Engineering

401 Sunset Ave, Windsor, Ontario, N9B 3P4, Canada

Phone: (519) 253-3000

Fax: (519) 971-3686

E-Mail Address:

tirupati@uwindsor.ca 


\begin{abstract}
Current scour estimation methods typically over-predict scour, resulting in uneconomical design. This tendency is partly due to the complexity of the scouring process, which indicates that some of its aspects are still not well understood, and can also be attributed to scale effects. Here, experiments are conducted to isolate the influence of relative coarseness $\left(D / d_{50}\right)$ and flow shallowness $(\mathrm{h} / \mathrm{D})$ on scour depth. For the range of $\mathrm{D} / \mathrm{d}_{50}$ in the present study, equilibrium scour depth $\left(\mathrm{d}_{\mathrm{se}} / \mathrm{D}\right)$ decreases with increasing $\mathrm{D} / \mathrm{d}_{50}$ until a limiting value of $\mathrm{D} / \mathrm{d}_{50}=175$, after which $\mathrm{d}_{\mathrm{se}} / \mathrm{D} \approx 0.75$. Furthermore, $\mathrm{d}_{\mathrm{se}} / \mathrm{D}$ is found to depend on $\mathrm{h} / \mathrm{D}$ when all other scour influencing parameters are held constant. A revised definition of the densimetric Froude number $\left(\mathrm{F}_{\mathrm{d}}\right)$ using the velocity along the separating streamline $\left(\mathrm{U}_{\mathrm{s}}\right)$ is shown to have an influential role in scour. An improved scour estimation method employing these parameters is presented and compared with current methods.
\end{abstract}

Keywords: scour, erosion, bridge pier scour, scour prediction, hydraulics 


\section{INTRODUCTION}

Several investigators have determined that local scour has caused a significant number of bridge collapses (Melville and Coleman 2000; Transportation Association of Canada 2001; Wardhana and Hadipriono 2003; Foti and Sabia 2011). Several national and state bridge design codes (e.g., AASHTO LRFD, OHBDC and CHBDC) include provisions for design of bridge piers with respect to scour on the basis of one of the several code-approved empirical equations. However, the commonly used equations have a tendency to over-predict the maximum value of equilibrium scour depth $\left(\mathrm{d}_{\mathrm{se}}\right)$, leading to uneconomical design (Ettema et al. 1998).

While our present understanding has improved and many scour depth prediction formulae are available, these methods often yield vastly different results, suggesting that many aspects of scour are still not well understood (Williams et al. 2013). The complexity of the scouring process and varied nature of the governing parameters are undoubtedly partially responsible for this. However, the scale effects arising from laboratory conditions are also a principal factor to which over-estimation of scour can be attributed.

In hydraulic modelling, the scale effects refer to an imbalance of force ratios between laboratory model and field prototype (Heller 2011). In scour modelling, the principal difficulty in scaling lies in the sediment size. While flow and pier properties can be scaled between field and laboratory by a common scale factor, similarly scaled sediment would behave cohesively and flow-sediment interactions in the field would not be accurately replicated in the model (Ettema et al. 1998). Therefore, the bed particle median diameter $\left(d_{50}\right)$ is generally similar in both the field and in the laboratory experiments. While this eliminates sediment cohesion, it also compromises similarity. Since the results from such experimentation have been used to derive 
empirical equations for predicting scour, the over-design of bridge pier scour depth is to be expected (Ettema et al. 1998; Briaud 2015; Johnson et al. 2015).

This investigation will further explore the role of relative coarseness $\left(D / d_{50}\right)$ and flow shallowness $(\mathrm{h} / \mathrm{D})$ on the estimation of equilibrium scour depth at bridge piers. Here, $\mathrm{D}$ is the pier diameter. Relationships between various non-dimensional quantities in scour investigations will be explored. To this end, two sets of tests that isolate the influences of $D / d_{50}$ and $h / D$ are conducted. An attempt is made to study the role of the velocity along the flow separating streamline $\left(\mathrm{U}_{\mathrm{s}}\right)$ which is also the maximum velocity in the flow field.

\section{PREVIOUS STUDIES}

\section{Role of Governing Parameters}

The current state of knowledge of scour around bridge piers provides justification for the need to change approaches recommended by current design guidelines (e.g., the HEC-18 equation) (Ettema et al. 2011). The variables which affect scour depth are many and related to characteristics of fluid, flow, pier, time and sediment. Based on experimental results, researchers have developed many formulae for predicting scour, the majority of which calculate equilibrium scour depth as a function of the parameters listed below:

$$
d_{s e}=f\left\{\rho, v, U, U_{c}, h, \rho_{s}, d_{50}, \sigma_{g}, g, D, S h, A l\right\}
$$

where $\rho=$ fluid density, $v=$ kinematic viscosity, $U=$ mean flow velocity, $U_{c}=$ critical velocity of sediment, $\rho_{\mathrm{s}}=$ sediment density, $\mathrm{d}_{50}=$ median sediment diameter, $\sigma_{\mathrm{g}}=$ standard deviation of particle size, $\mathrm{g}=$ gravitational acceleration, $\mathrm{Sh}$ and $\mathrm{Al}=$ parameters describing pier shape and alignment. 
Equation 1 can be further reduced to a set of non-dimensional parameters (Equation 2); this is contingent on maintenance of constant pier shape, flow alignment, uniform sediment, high Reynolds number and subcritical Froude number:

$$
\frac{\mathrm{d}_{\mathrm{se}}}{\mathrm{D}}=\mathrm{f}\left\{\frac{\mathrm{U}}{\mathrm{U}_{\mathrm{c}}}, \frac{\mathrm{h}}{\mathrm{D}}, \frac{\mathrm{D}}{\mathrm{d}_{50}}, \mathrm{~F}_{\mathrm{d}}\right\}
$$

In Equation 2, $F_{d}$ is the densimetric Froude number, which is defined by Equation 3 (here, SG refers to specific gravity of sediment):

$$
\mathrm{F}_{\mathrm{d}}=\frac{\mathrm{U}}{\sqrt{\mathrm{g}(\mathrm{SG}-1) \mathrm{d}_{50}}}
$$

Scale effects in scour modelling occur due to the difficulty in simultaneously satisfying three length scales in scour models, which are included in the dimensionless quantities of Equation 2: h, D, and $\mathrm{d}_{50}$ (Ettema et al. 2011). The geometric factor by which all other variables are scaled is not consistent for sediment size. As a result, it is very difficult to derive a distinct relationship between very large or field-level values of relative coarseness and relative scour depth obtained experimentally (Lee and Sturm 2009).

Prior experimentation has demonstrated the effect of each of the variables in Equation 2 on scour depth and geometry, particularly under clear-water conditions. Perhaps the most influential parameter relating to sediment size is the ratio of pier diameter to median sediment grain size, $D / d_{50}$. The relationship between relative sediment size or relative coarseness $\left(D / d_{50}\right)$ and relative scour depth $\left(\mathrm{d}_{\mathrm{se}} / \mathrm{D}\right)$ has some inconsistencies. It has been shown that the relative scour depth decreases with increasing $D / d_{50}$ for $D / d_{50}$ greater than 50 , before reaching constancy at $\mathrm{D} / \mathrm{d}_{50} \approx 200$. However, relative scour depth has been shown to fluctuate at very large values of $\mathrm{D} / \mathrm{d}_{50}$, for reasons which are unclear as one of the challenges in scour modelling lies in the inability of a model to accurately represent a field value of $\mathrm{D} / \mathrm{d}_{50}$. 
In experimentation and in the field, piers are classified as narrow, wide or intermediate depending on the value of $\mathrm{h} / \mathrm{D}$ in the case under consideration. Narrow piers are the most commonly studied group, for which $\mathrm{h} / \mathrm{D}$ is greater than 1.4 . For narrow piers, maximum scour depth occurs at the upstream face of the pier (Ettema et al. 2011). As flow depth increases, its influence on scour depth increases, and the influence of pier size on scour depth decreases, until a limiting point $(\mathrm{h} / \mathrm{D}=1.4)$ at which these influences reverse. In effect, after $\mathrm{h} / \mathrm{D}$ exceeds 1.4 , flow depth no longer influences scour depth and $d_{s e} / D$ becomes constant (Johnson and Torrico 1995).

Many investigations focus on clear-water scour, which is defined by the critical velocity of sediment $\left(\mathrm{U}_{\mathrm{c}}\right)$ and mean flow velocity $(\mathrm{U}) . \mathrm{U}_{\mathrm{c}}$ is the flow velocity at which incipient motion of sediment will occur, and must be determined for each sediment type under consideration. If $U$ exceeds $U_{c}\left(U / U_{c}>1\right)$, then the sediment will be transported by the flow and scouring action is classified as live-bed; if $\mathrm{U} / \mathrm{U}_{\mathrm{c}}$ is held below unity, then clear-water conditions will be maintained, which is typical of flow over alluvial sand beds (Ettema et al. 2011). Previous studies have shown that the effect of $U / U_{c}$ on scour is subdued compared to the influences of flow shallowness (Melville and Coleman 2000).

The role of the densimetric Froude number $\left(\mathrm{F}_{\mathrm{d}}\right)$ in the scour process has been considered. $F_{d}$ had been previously established as a scour-influencing parameter of note, but had yet to be explored experimentally. It has been determined that even for small changes in $\mathrm{F}_{\mathrm{d}}$ (i.e., between 2.1 and 2.5 ), there were changes in scour geometry, particularly in the contour profiles (Hodi 2009).

Further challenges in hydraulic modelling are related to other parameters which influence scour depth, as conditions in the field are less consistent when compared with a laboratory set- 
up. For example, bed material size is purposely uniform in the laboratory, which is not often the case in natural flow systems. Furthermore, the channel aspect ratio in laboratory flows tends to be small, generating strong secondary flows. In conclusion, the presently available literature indicates that further investigation of the role of scour-governing parameters is required.

\section{Scour Depth Estimation Methods}

This review and subsequent analysis will focus on two predictive methods which are functions of the aforementioned non-dimensional parameters. The equations were selected on the basis of commonality of use in practice, practicality or applicability to considered results in the analysis, and relative recentness of development.

\section{(i) HEC-18 or Colorado State University Equation (2001):}

The most commonly used equation for prediction of equilibrium scour depth is the HEC18 or CSU equation, which was published by the Hydraulic Engineering Circular No. 18 in 1993. The HEC-18 equation, also uses "K" correction factors and can be used for clear-water and livebed conditions (Deng and Cai 2010).

The first version of the HEC-18 equation included three correction factors, which accounted for pier nose shape, angle of attack of approach flow, and bed conditions, respectively; a fourth $\mathrm{K}$ factor was added to the equation in 2001 , and was intended to adjust $\mathrm{d}_{\mathrm{se}} / \mathrm{D}$ based on armoring conditions by bed material size:

$$
\frac{d_{s e}}{D}=2.0 \mathrm{~K}_{1} \mathrm{~K}_{2} \mathrm{~K}_{3} \mathrm{~K}_{4}\left(\frac{h}{D}\right)^{0.35} \mathrm{~F}_{\mathrm{r}}^{0.43}
$$

\section{(ii) Sheppard-Melville (S/M) Equation (2014):}


The Sheppard-Melville equation approaches scour depth prediction through consideration of interactions between flow, structure, and sediment, in order to obtain the maximum potential scour depth (Sheppard et al. 2014):

$$
\begin{gathered}
\frac{d_{s e}}{D}=2.5 \mathrm{f}_{1} \mathrm{f}_{2} \mathrm{f}_{3} \\
\mathrm{f}_{1}=\tanh \left[\left(\frac{h}{D}\right)^{0.4}\right] \\
\mathrm{f}_{2}=\left\{1-1.2\left[\ln \left(\frac{U}{U_{c}}\right)\right]^{2}\right\} \\
\mathrm{f}_{3}=\left[\frac{\left(\frac{a^{*}}{D_{50}}\right)}{0.4\left(\frac{a^{*}}{D_{50}}\right)^{1.2}+10.6\left(\frac{a^{*}}{D_{50}}\right)^{-0.13}}\right]
\end{gathered}
$$

Commonly used predictive methods have been compared using experimental data in order to determine any limitations on their use. It has been determined that many equations overpredict $d_{\mathrm{se}} / \mathrm{D}$ to varying degrees. For large-scale tests, the HEC-18 equation was the most accurate method of prediction (Williams et al. 2013). The most recently developed estimation method (the S/M equation) and the most commonly used method (the HEC-18 equation) are used for further analysis in this investigation.

\section{METHODOLOGY}

Based on the parametric considerations in the above literature review, experimental conditions were chosen as described below. Experimentation was divided into two sets, each with two subsets of tests (shown in Table 1). Set I consisted of twelve tests, with six tests each for $\mathrm{d}_{50}=0.51 \mathrm{~mm}$ (subset “A”) and $\mathrm{d}_{50}=0.77 \mathrm{~mm}$ (subset "B"). In both subsets, pier diameter D was decreased, such that $\mathrm{D} / \mathrm{d}_{50}$ decreased incrementally for each test. For each test in set I, flow shallowness $(\mathrm{h} / \mathrm{D}=1.6)$, flow intensity $\left(\mathrm{U} / \mathrm{U}_{\mathrm{c}}=0.85\right)$ and blockage ratio $(\mathrm{D} / \mathrm{b}=0.10)$ were held 
constant, such that the varying non-dimensional parameter was relative coarseness. Flow shallowness was maintained above 1.4 in order to ensure that piers were classified as narrow (Melville and Coleman 2000). The flow Reynolds number was held high enough $(\operatorname{Re}>10,000)$ to maintain fully turbulent conditions and the flow was subcritical $(\mathrm{Fr}<0.30)$. The purpose of all set I tests was to isolate the effects of $\mathrm{D} / \mathrm{d}_{50}$ on relative scour depth.

In set II, two subsets of tests ("E" and "F") were carried out in each sand bed in order to investigate the effects of flow shallowness (h/D) on scour geometry. In both subsets, flow depth $h$ was increased such that $h / D$ increased incrementally for each test. For all subset $E$ tests, D/d 50 was maintained at 118; for all subset $F$ tests, $D / d_{50}$ was maintained at 78 . As with set $\mathrm{I}, \mathrm{U} / \mathrm{U}_{\mathrm{c}}$ was held constant at 0.85 and $\mathrm{D} / \mathrm{b}$ was held constant at 0.10 for all tests.

Experiments were carried out in a horizontal flume with a length of $10.5 \mathrm{~m}$, a width of 1.22 $\mathrm{m}$, and a height of $0.84 \mathrm{~m}$. In order to reduce the turbulence level in the flow, a flow straightener was situated at the upstream end of the flume. A plywood approach ramp allowed flow progression on to a plywood sediment box. An ASTM sieve analysis was performed for the two sands used in the tests in order to determine the grain size distribution and relevant characteristics of each. The $\mathrm{d}_{50}$ values were found to be $0.51 \mathrm{~mm}$ and $0.77 \mathrm{~mm}$ and the standard deviation of particle size $\left(\sigma_{\mathrm{g}}\right)$ for each sediment type was found to be 1.16 and 1.34 , respectively.

For each test, the appropriate sand was placed in the sand box inside the flume. Following this, the walls were positioned in the sand bed such that the desired flume width was achieved in order to maintain a constant D/b ratio in all tests (Figure 1). The bed material was then levelled using a flat trowel and a model pier was centered between the walls. A 25-mm sand trip was located $1 \mathrm{~m}$ ahead of the location of the pier, to potentially trip the boundary layer to a turbulent state. Finally, the flume was filled to the desired water depth, the pump was turned on 
and the flow controller adjusted to sustain a flow intensity of 0.85 . The depth-averaged velocity of the approach flow, U, was verified for each test using an acoustic Doppler velocimeter (ADV, Nortek USA). The velocity profile measured with the ADV validated the log-law profile in the absence of the pier. The flow was fully developed at the location of the pier.

Several preliminary tests covering a range of time periods $(24 \mathrm{hrs}<\mathrm{t}<96 \mathrm{hrs})$ were conducted prior to the start of the experiments. It was noticed that the change in the scour profiles in both the transverse and flow directions were not significant for $\mathrm{t} \geq 48 \mathrm{hrs}$. Consequently, all tests were conducted for a period of 48 hours and the resulting scour geometry was considered to be at an equilibrium state (D'Alessandro 2013). Following the 48-hour period, the flume was drained gradually to avoid displacement of bed material. The centreline and contour profiles of the scour hole were measured using a laser distance meter mounted on a biaxial traverse.

\section{RESULTS AND DISCUSSION}

\section{Set I: Effect of Relative Coarseness, $\mathbf{D} / \mathbf{d}_{50}$}

The normalised centreline and contour profiles of scour for subset A tests are shown in Figures 2a and 2c, respectively, and profiles for subset B tests are shown in Figures $\mathbf{2 b}$ and $\mathbf{2 d}$. The origin for each profile is located at the geometric centre of the pier. The x-axis is in the direction of flow, the $y$-axis is transverse to the flow, and the z-axis is in the vertical direction. The profiles shown in Figure 2 indicate that the scour form is similar for all the tests. In general, scour depth increases from the start of the scour hole to the upstream face of the pier. Downstream of the pier, scour depth decreases with increasing $\mathrm{x} / \mathrm{D}$ until returning to the mean 
bed level. Immediately downstream of the scour hole, a deposit of sediment is formed above the mean bed level.

The results of Figure 2 (also shown in Table 2) indicate that, over the range of $D / d_{50}$ in subsets $A$ and $B$, scour decreases with increasing $D / d_{50}$ until $D / d_{50}=175$, after which $d_{s e} / D$ becomes constant. The influence of $\mathrm{D} / \mathrm{d}_{50}$ on scour depth and geometry were found to be smaller upstream of the pier (Figures 2a and 2b) compared to changes in scour downstream of the pier. This is illustrated in the inset of Figure 2b, where the relative scour depth at the downstream face of the pier generally decreases with increasing $\mathrm{D} / \mathrm{d}_{50}$ when $\mathrm{D} / \mathrm{d}_{50}$ is greater than 78 .

Figures $\mathbf{2 a}$ and $\mathbf{2 b}$ show that the sediment deposit formed downstream of the pier has large three-dimensional dune-like features. The length of such a deposit, denoted by the distance from which the first dune commences and ends at the zero-bed level, is shown in Figure $\mathbf{2 b}$ for test B2. The deposit length for all tests with $\mathrm{d}_{50}=0.77 \mathrm{~mm}$ was less than six pier diameters (6D), while in Figure 2a, it can be seen that the deposit length for tests with $\mathrm{d}_{50}=0.51 \mathrm{~mm}$ was greater than 6D with multiple dune formations. Ripples also formed on the primary deposits in the sand bed with $\mathrm{d}_{50}=0.51 \mathrm{~mm}$, which is typical for sediments with $\mathrm{d}_{50}$ less than $0.70 \mathrm{~mm}$.

In Figure 2c, scour profiles for subset $A\left(d_{50}=0.51 \mathrm{~mm}\right)$ reached the sidewalls of the flume. This indicates that side wall interference affected scouring action for all tests with the finer sediment. For subset B $\left(\mathrm{d}_{50}=0.77 \mathrm{~mm}\right)$ shown in Figure 2d, none of the contour profiles of scour for these tests extended as far as the sidewalls. Therefore, wall interference had a greater effect on scour in beds with smaller median sediment diameter. It is important to note that $\mathrm{D} / \mathrm{b}$ is held constant in all tests. As all other non-dimensional parameters are held constant between subset $\mathrm{A}$ and subset $\mathrm{B}$, it follows that sidewall influences must increase due to an additional sediment-related non-dimensional parameter. Furthermore, for subset A tests, scour generally 
reached the sidewalls at a shorter distance downstream of the pier for greater values of $\mathrm{D} / \mathrm{d}_{50}$. Again, while the variation in $\mathrm{d}_{\mathrm{se}}$ is very small for larger values of $\mathrm{D} / \mathrm{d}_{50}$, the downstream geometry of scour shows greater discrepancies. This is shown in both the nature and length of the primary deposit downstream of the scour hole, as well as in the propensity of scouring action in reaching the sidewalls of the channel.

Figure 3 indicates that the maximum relative scour depth and relative scour width also decreased consistently with increasing $\mathrm{D} / \mathrm{d}_{50}$ values, confirming the influence of $\mathrm{D} / \mathrm{d}_{50}$ on equilibrium scour depth (Lee and Sturm 2009). For greater values of $D / d_{50}>175, d_{s e} / D$ is relatively constant, which suggests that the effects of relative coarseness are dampened over the range of $D / d_{50}$ covered by this investigation. This correlation between $d_{s e} / D$ and $D / d_{50}$ is clearly shown by the results in subset A and subset B when each subset is viewed separately.

Between the two subsets of set I experimentation, there are pairs of tests with very similar values of $\mathrm{D} / \mathrm{d}_{50}$ (represented by dotted ellipses in Figure 3); for example, B3 with $\mathrm{D} / \mathrm{d}_{50}=115$ and A6 with $\mathrm{D} / \mathrm{d}_{50}=118, \mathrm{~B} 2$ with $\mathrm{D} / \mathrm{d}_{50}=131$ and A5 with $\mathrm{D} / \mathrm{d}_{50}=137$, or B1 with $\mathrm{D} / \mathrm{d}_{50}=157$ and $\mathrm{A} 4$ with $\mathrm{D} / \mathrm{d}_{50}=156$. Again, flow shallowness, blockage ratio $(\mathrm{D} / \mathrm{b})$, and flow intensity are constant for all of these tests. If $\mathrm{D} / \mathrm{d}_{50}$ were indeed the only remaining governing nondimensional parameter, then it would follow that tests with similarly close values of relative coarseness should result in scour profiles which are nearly identical. However, the results presented in Figure 4 do not support this assumption. In effect, if $\mathrm{D} / \mathrm{d}_{50}, \mathrm{~h} / \mathrm{D}, \mathrm{D} / \mathrm{b}$, and $\mathrm{U} / \mathrm{U}_{\mathrm{c}}$ are held constant, changes persist in $\mathrm{d}_{\mathrm{se}} / \mathrm{D}$ (the primary scour dimension of concern with respect to design). Again, this is indicative of an additional sediment-related non-dimensional parameter, which governs scour. Through analysis of experimental results (to be discussed below), this was determined to be the densimetric Froude number, $F_{d}$ (Equation 3). The densimetric Froude 
number is representative of the ratio between the inertial force on each bed particle and its submerged specific weight (Hodi 2009).

The contour profiles for tests A4, A5, and A6 show that scour reached the sidewalls, which did not occur for tests B1, B2, or B3; this confirms that sidewall influences vary with changing sediment size and therefore with densimetric Froude number. For tests in subset A $\left(\mathrm{d}_{50}\right.$ $=0.51 \mathrm{~mm}), F_{d}$ is 2.40 . For tests in subset $B\left(d_{50}=0.77 \mathrm{~mm}\right), F_{d}$ is 2.30 . Therefore, effects of wall interference increase with increasing $F_{d}$. Furthermore, when all other non-dimensional parameters are held constant, $d_{s e} / D$ increases with increasing $F_{d}$, even for very small changes in $\mathrm{F}_{\mathrm{d}}$

In conclusion, it has been determined that $d_{s e} / D$ decreases with increasing $D / d_{50}$ until a limiting value of $\mathrm{D} / \mathrm{d}_{50}=175$, after which $\mathrm{d}_{\mathrm{se}} / \mathrm{D}$ reaches a constant value of approximately 0.75 , which is in agreement with literature (Lee and Sturm 2009). In addition, the densimetric Froude number (representative of flow-sediment interactions) has been shown to affect $\mathrm{d}_{\mathrm{se}} / \mathrm{D}$.

\section{Set II: Effect of Flow Shallowness, h/D}

The majority of test conditions in subset $\mathrm{E}$ are the same as those of test A6, with varying values of water height, $h$. By holding $\mathrm{d}_{50}, \mathrm{D} / \mathrm{d}_{50}, \mathrm{D} / \mathrm{b}$, and $\mathrm{U} / \mathrm{U}_{\mathrm{c}}$ constant, the influences of $\mathrm{h} / \mathrm{D}$ on scour were isolated for each subset. Similarly, test conditions in subset F were identical to those of test B6, with the exception of flow shallowness, h/D. Figure 5 shows the centreline and contour profiles of scour for all tests in subset E and F. As with the tests in set I, Figures 5a and 5b show that the scour profiles for tests with increasing $h / D$ are very similar in form. For tests with $\mathrm{d}_{50}=0.51 \mathrm{~mm}$, the majority of primary sediment deposits are of shorter relative length than for tests with $\mathrm{d}_{50}=0.77 \mathrm{~mm}$. Ripples are also present on the primary deposits for the subset $\mathrm{E}$ tests. The profiles in Figure 5 and the results of Figure 2 indicate that, over the range of h/D 
presented in subsets $\mathrm{E}$ and $\mathrm{F}$, scour increases with $\mathrm{h} / \mathrm{D}$ before reaching constancy between $\mathrm{h} / \mathrm{D}$ values of 2.0 and 3.2. After this, scour begins to decrease.

The effects of sidewall interference are once again clearly visible in Figures $\mathbf{5 c}$ and $\mathbf{5 d}$. In tests E1 through E6 $\left(\mathrm{d}_{50}=0.51 \mathrm{~mm}, \mathrm{D} / \mathrm{d}_{50}=118\right)$, scour reaches the sidewalls at a shorter distance downstream than in tests $\mathrm{F} 1$ through $\mathrm{F} 5\left(\mathrm{~d}_{50}=0.77 \mathrm{~mm}, \mathrm{D} / \mathrm{d}_{50}=78\right)$, indicating again that the effects of wall interference are increased in the finer sediment. Therefore, the wall interference effect is shown to have a greater influence on sediment-structure interactions with increasing $\mathrm{D} / \mathrm{d}_{50}$ values, as was demonstrated by set I tests.

In both subset $\mathrm{E}$ and $\mathrm{F}$ tests, the distance downstream of the pier at which scour reached the sidewalls decreased with increasing $h / D$ until $h / D=3.2$. After this point, the relative size and depth of the scour hole decreased and scour reached the sidewalls at a farther distance downstream of the pier. Similarly, the scour in the two tests with the lowest $d_{\text {se }} / D$ in subset F (F5 and F1, Figures 5c and 5d) did not reach the sidewalls at all. Therefore, effects of wall interference increase with increasing $h / D$, until a limiting value of $h / D=3.2$.

Figure 6 shows the relationship between scour geometry and flow shallowness. Both graphs show that $d_{s e} / D$ and $w_{s} / D$ generally increase with increasing $h / D$ until a limiting value of 3.2, after which $d_{s e} / D$ appears to decrease. A system of pier designation based on values of $h / D$ has been introduced, such that narrow piers were defined as those with $\mathrm{h} / \mathrm{D}$ values greater than 1.4; scour around piers of a narrow classification is highly dependent on pier diameter D. In the intermediate range of piers $(0.2 \leq \mathrm{h} / \mathrm{D} \leq 1.4)$, it has been shown that the square root of hD has the greatest influence on $\mathrm{d}_{\text {se. }}$. Finally, in the wide range of piers, for which $\mathrm{h} / \mathrm{D}$ is less than 0.2 , flow depth has been shown to have the greatest influence on scour (Melville and Coleman 2000). According to these definitions, the value of $d_{s e} / D$ for $h / D$ values greater than 1.4 should be a 
constant, regardless of water height (Ettema et al. 2011). However, subset E and F results in set II of testing indicate that $\mathrm{d}_{\mathrm{se}} / \mathrm{D}$ does change with increasing values of $\mathrm{h} / \mathrm{D}$ beyond 1.4 , refuting the convention that high values of $\mathrm{h} / \mathrm{D}$ do not influence scour.

When comparing subset $\mathrm{E}$ and subset $\mathrm{F}$, there are dissimilarities in scour even in tests with constant h/D. Figure 7 shows scour profiles for three pairs of tests (E2 and F2, E3 and F3, and E4 and F4), in order to show comparison in tests with varying $\mathrm{D} / \mathrm{d}_{50}$ at higher $\mathrm{h} / \mathrm{D}$ values. These figures indicate that the effects of $D / d_{50}$ on $d_{s e} / D$ are reversed at higher values of $h / D$. In subset $A$ and $B$, with $h / D=1.6$ for all tests, $d_{s e} / D$ consistently decreased with increasing $D / d_{50}$ until a limiting value of $\mathrm{D} / \mathrm{d}_{50}=175$, after which the relationship between the two parameters reached constancy. However, these comparative figures indicate that at higher values of h/D, relative scour is greater in depth and profile for tests with $\mathrm{D} / \mathrm{d}_{50}=118$ (subset $\mathrm{E}$ ) when compared with the same for tests with $\mathrm{D} / \mathrm{d}_{50}=78$ (subset $\mathrm{F}$ ).

As with set I tests, the differences in scour geometry downstream of the pier between tests in different sands are highlighted above. In Figure 7, the centreline and contour profile comparisons for each pair of tests shows that scour upstream of the pier is very similar (and in the case of E2 and E4, nearly identical). Figure 6 also shows that maximum scour depth and width for these tests are similar, with $\mathrm{d}_{\mathrm{se}} / \mathrm{D}$ and $\mathrm{w}_{\mathrm{s}} / \mathrm{D}$ for subset $\mathrm{F}$ tests being slightly lesser.

In Figures 7a, 7b and 7c, the primary deposits for subset $E$ tests with $\mathrm{d}_{50}=0.51 \mathrm{~mm}\left(\mathrm{~F}_{\mathrm{d}}\right.$ $=2.40$ ) are shown to be significantly different from those for subset $\mathrm{F}$ tests with $\mathrm{d}_{50}=0.77 \mathrm{~mm}$ $\left(F_{d}=2.30\right)$. In Figure 7a and $7 \mathbf{b}$, the length of the scour holes in E3 and E4 are greater than the length of the scour holes in F3 and F4, and bed ripples begin to form within the hole itself. In Figure 7c, where the length of the scour holes for both tests E2 and F2 are very similar, the form and height of the primary deposits are still very different. 
In Figure 7, the effects of sidewall interference on scour can also be seen. In each figure, point B2 is the point at which the figure's subset $\mathrm{F}$ test reaches the sidewall; point B1 is the point at which the figure's subset E test reaches the sidewall. In all cases, B2 is located at a greater distance downstream of the pier than B1, indicating again that the effects of wall interference on scouring action are greater in smaller sediment (or greater $F_{d}$, in the case of set II tests), despite constant $\mathrm{h} / \mathrm{D}, \mathrm{D} / \mathrm{b}$ and $\mathrm{U} / \mathrm{U}_{\mathrm{c}}$.

In conclusion, $d_{s e} / D$ increases with increasing $h / D$ but remains constant for $2<h / D<3.2$. Melville and Coleman's trendline (which indicates that $d_{s e} / D$ is constant for $h / D>1.4$ ) is not valid when the influences of $\mathrm{h} / \mathrm{D}$ are isolated. It should be remarked that the figure provided by Melville and Coleman is a log-log plot and the extrapolation of experimental data trend to a constant value should be used with caution. The influence of wall interference on scour is also more pronounced for tests with greater values of densimetric Froude number $\left(F_{d}\right)$, even with h/D, $\mathrm{D} / \mathrm{b}$ and $\mathrm{U} / \mathrm{U}_{\mathrm{c}}$ held constant.

\section{Development of a New Scour Depth Prediction Method}

As previously discussed, the principal non-dimensional factors typically used in scour estimation methods are relative coarseness $\left(D / d_{50}\right)$, flow shallowness $(h / D)$, and flow intensity $\left(\mathrm{U} / \mathrm{U}_{\mathrm{c}}\right)$. However, the experiments in this investigation have shown that even when all three quantities are held constant, there are additional parameters which are shown to affect the scouring action. The first of these is the densimetric Froude number, $F_{d}$, which is representative of flow-sediment interactions, and the second parameter is wall interference due to blockage, which can be important in laboratory-scale experiments.

Figure 8a shows the relationship between $d_{s e} / D$ and $D / d_{50}$ from recent investigations. The figure shows that while there is a decreasing trend, there is no distinct single curve upon 
which the data can be collapsed. There is a large amount of scatter in the relationship, which implies that there are other influencing parameters. However, when grouped by values of densimetric Froude number, $F_{d}$ (Figure 8b), a trend tends to appear. At least part of the scatter in the data can be attributed to varying values of $F_{d}$, with $d_{s e} / D$ decreasing with even minimal changes in $F_{d}$. Since $F_{d}$ is representative of flow-sediment interactions, it was chosen as a primary parameter for estimation of relative scour depth. Therefore, the relationship between $d_{s e} / D$ and $F_{d}$ can be determined in terms of $D / d_{50}$, which indicates that while $D / d_{50}$ may not be a governing parameter of the highest importance, it still has an influence on $d_{s e} / D$, particularly when compared with other non-dimensional quantities.

Furthermore, analysis indicates that the flume sidewall also influences the scour process, leading to a closer examination of the flow field surrounding the pier. Flow velocity increases around the pier from a stagnation point on its upstream face, where $U=0$ and pressure is a maximum. This velocity reaches a maximum value at the point of separation (denoted as $U_{s}$ ), initiates scour. The value of $U_{s}$ is a function of the base pressure on the downstream face of the pier, and can therefore be determined when the base pressure coefficient is known (Roshko 1961; Norberg 1987). It is important to note that $U_{s}$ has been identified as the proper velocity scale and effects of wall interference can be reduced or eliminated by the use of $U_{s}$ in the case of flow past bluff bodies (Ramamurthy 1973).

Flow velocity in $F_{d}$ is replaced with $U_{s}$, yielding the term $F_{d s}$ (Equation 6), as $U_{s}$ is the highest value of velocity encountered in the vicinity of cylinder. This is the first point where scour is initiated and also incorporates a parameter which would account for the correction due to sidewall interference.

$$
\mathrm{F}_{\mathrm{ds}}=\frac{\mathrm{U}_{\mathrm{s}}}{\sqrt{\mathrm{g}(\mathrm{SG}-1) \mathrm{d}_{50}}}
$$


As previously discussed, when isolated, relative coarseness and flow shallowness influences on relative scour depth are evident. Therefore, the three parameters used for estimation of $d_{\text {se }}$ were chosen to be $F_{d s}, h / D$, and $D / d_{50}$. As the general trend of relationships between each parameter and $d_{s e} / D$ were exponential in nature, the form of the equation is written as:

$$
\frac{\mathrm{d}_{\mathrm{se}}}{\mathrm{D}}=\mathrm{C}\left(\mathrm{F}_{\mathrm{ds}}\right)^{\mathrm{n}_{1}}\left(\frac{\mathrm{h}}{\mathrm{D}}\right)^{\mathrm{n}_{2}}\left(\frac{\mathrm{D}}{\mathrm{d}_{50}}\right)^{\mathrm{n}_{3}}
$$

Here, $\mathrm{C}$ is a constant. Based on the experimental data, the values of each exponent $\mathrm{n}$ and constant $\mathrm{C}$ in Equation 7 are evaluated and the equation is re-written as:

$$
\frac{\mathrm{d}_{\mathrm{se}}}{\mathrm{D}}=1.010\left(\mathrm{~F}_{\mathrm{ds}}\right)^{-0.284}\left(\frac{\mathrm{h}}{\mathrm{D}}\right)^{0.325}\left(\frac{\mathrm{D}}{\mathrm{d}_{50}}\right)^{0.059}
$$

Figure 9 shows the relationship between experimentally measured and predicted values of $\mathrm{d}_{\mathrm{se}}$ /D using the HEC-18 equation, the Sheppard-Melville equation and Equation 8. In the graphs, the subscripts $m$ and $p$ refer to the measured and predicted values. The solid line is at 45 degrees to the horizontal. As seen in Figures 9a and 9b, both HEC-18 and S/M equations significantly over-predict $\mathrm{d}_{\mathrm{se}} / \mathrm{D}$. In addition, Figures 9a and $\mathbf{9 b}$ show more scatter than Figure 9c. Results from an investigation on large-scale experimentation are included (Sheppard et al. 2004), as well as field measurements from various investigations (Froehlich 1989).

In conclusion, Equation 8 offers a reasonable estimate of $\mathrm{d}_{\mathrm{se}} / \mathrm{D}$ under clear-water scour conditions, particularly when compared with the Sheppard-Melville equation and the HEC-18 equation. While the HEC-18 equation had previously been determined to offer the most accurate prediction of $d_{s e} / D$ in large-scale tests (Williams et al. 2013), the correlation between $\left(d_{s e} / D\right)_{p}$ calculated using Equation 8 and $\left(\mathrm{d}_{\mathrm{se}} / \mathrm{D}\right)_{\mathrm{m}}$ was found to be stronger than the correlation between $\left(\mathrm{d}_{\mathrm{se}} / \mathrm{D}\right)_{\mathrm{p}}$ calculated using the HEC-18 equation and $\left(\mathrm{d}_{\mathrm{se}} / \mathrm{D}\right)_{\mathrm{m}}$ for several experiments. This 
includes the results of the current investigation as well as results from large-scale tests and field measurements of scour. The Sheppard-Melville equation was not used to predict $d_{s e} / D$ for field measurements, as it requires a value of $U / U_{c}$ which was not available.

\section{CONCLUSIONS}

Many of the scour prediction methods used in practice are functions of relative coarseness $\left(\mathrm{D} / \mathrm{d}_{50}\right)$, flow shallowness $(\mathrm{h} / \mathrm{D})$, and flow intensity $\left(\mathrm{U} / \mathrm{U}_{\mathrm{c}}\right)$, which are used to calculate relative scour depth $\left(\mathrm{d}_{\mathrm{se}} / \mathrm{D}\right)$ for the purposes of design. These non-dimensional parameters are representative of interactions between the three main components of scour: flow, sediment, and structure. In this investigation, various parameter influences in scour experimentation were explored in order to develop a scour depth estimation method. Two sets of testing were carried out in order to investigate the effects of $D / d_{50}$ and $h / D$ on $d_{s e} / D$. Experimental results were used to develop a new scour-prediction equation. The following conclusions can be drawn from the investigation:

- $\mathrm{d}_{\mathrm{se}} / \mathrm{D}$ decreases with increasing $\mathrm{D} / \mathrm{d}_{50}$ until a limiting value of $\mathrm{D} / \mathrm{d}_{50}=175$, after which $d_{s e} / D$ reaches a constant value of approximately 0.75 , which is in agreement with Lee and Sturm's (2009) trendline.

- $\mathrm{d}_{\mathrm{se}} / \mathrm{D}$ increases with increasing $\mathrm{h} / \mathrm{D}$ for values above $\mathrm{h} / \mathrm{D}=1.4$, until $\mathrm{h} / \mathrm{D}=2.0$ to $\mathrm{h} / \mathrm{D}=$ 3.2, over which range $d_{s e} / D$ is constant; however, $d_{\text {se }} / D$ decreases again for values of $h / D$ > 3.2; therefore, the Melville and Coleman's trendline (for which $d_{\mathrm{se}} / \mathrm{D}$ is constant for $\mathrm{h} / \mathrm{D}>1.4)$ is not valid when the influences of $\mathrm{h} / \mathrm{D}$ are isolated.

- In tests with similar values of $\mathrm{D} / \mathrm{d}_{50}$ or $\mathrm{h} / \mathrm{D}, \mathrm{D} / \mathrm{b}$ and $\mathrm{U} / \mathrm{U}_{\mathrm{c}}$, densimetric Froude number $\left(\mathrm{F}_{\mathrm{d}}\right)$ is shown to affect scour depth and geometry. 
- Similarly, variation in flow velocity at the point of separation around the pier $\left(\mathrm{U}_{\mathrm{s}}\right)$ also affects scour.

- A non-dimensional parameter $\left(\mathrm{F}_{\mathrm{ds}}\right)$ was defined and incorporated into a new scour estimation method; this new estimation method was compared with current best practices and demonstrated greater accuracy in prediction of relative equilibrium scour depth $\left(d_{\mathrm{se}} / \mathrm{D}\right)$.

\section{REFERENCES}

American Association of State Highway and Transportation Officials. 2012. AASHTO LRFD Bridge Design Specifications. American Association of State and Highway Transportation Officials, Washington, D.C.

Briaud, J. 2015. Scour depth at bridges: Method including soil properties. I: Maximum scour depth prediction. J. Geotech. geoenviron. eng. 141(2).

CSA International, Standards Council of Canada. 2006. Canadian Highway Bridge Design Code, CAN/CSA-26-06. Canadian Standards Association, Toronto, ON.

D'Alessandro, C. 2013. Effect of blockage on circular cridge pier local scour. M.A.Sc. thesis, Department of Civil and Environmental Engineering, University of Windsor, Windsor, ON.

Deng, L. and Cai, C. 2010. Bridge scour: prediction, modeling, monitoring, and countermeasures — review. Pract Period Struct Des Construct. 15(2): 125-134. 
Ettema, R., Melville, B., and Barkdoll, B. 1998. Scale effects in pier-scour experiments. J. Hydraul. Eng. 124(6): 639-642.

Ettema, R., Kirkil, G., and Muste, M. 2006. Similitude of large-scale turbulence in experiments on local scour at cylinders. J. Hydraul. Eng. 132(1): 33-40.

Ettema, R., Constantinescu, G., Melville, B. 2011. NCHRP Web-Only Document 175:

Evaluation of bridge scour research: pier scour processes and predictions. Available from http://onlinepubs.trb.org/onlinepubs/nchrp/nchrp_w175.pdf [accessed 1 May 2013].

Foti, S. and Sabia, D. 2011. Influence of foundation scour on the dynamic response of an existing bridge. J. Bridge. Eng. 16(2): 295-304.

Froehlich, D. 1988. Analysis of on-site measurements of scour at piers. In Proceedings of the 1988 ASCE National Hydraulic Engineering Conference, Colorado Springs, CO, August 8-12, 1988. American Society of Civil Engineers, New York, NY.

Heller, V. 2011. Scale effects in physical hydraulic engineering models. J. Hydraul. Res. 49(3): 293-306. 
Hodi, B. 2009. Effect of blockage and densimetric Froude number on dircular bridge pier scour. M.A.Sc. thesis, Department of Civil and Environmental Engineering, University of Windsor, Windsor, ON.

Johnson, P. and Torrico, E. 1995. Scour around wide piers in shallow water. Transport. Res. Rec. (1471): 66-70.

Johnson, P. A., Clopper, P.E., Zevenbergen, L.W., and Lagasse, P.F. 2015. Quantifying uncertainty and reliability in bridge scour estimations. J. Hydraul. Eng. 141(7): 04015013.

Lee, S. and Sturm, T. 2009. Effect of sediment size scaling on physical modeling of bridge pier scour. J. Hydraul. Eng.135(10): 793-802.

Melville, B., and Coleman, S. 2000. Bridge scour. Water Resources Publications, Colorado, USA.

Norberg, C. 1987. Effects of Reynolds number and a low-intensity freestream turbulence on the flow around a circular cylinder. Chalmers University, Goteborg, Sweden, Technological Publications, 87(2).

Ontario Ministry of Transportation, Quality and Standards Division .1991. Ontario Highway Bridge Design Code, $3^{\text {rd }}$ edition. Ontario Ministry of Transportation, Quality and Standards Division, Canada. 
Ramamurthy, A S. 1973. Wall effects on flow past bluff bodies. J. Sound Vibration. 31(4): 44351.

Roshko, A. 1961. Experiments on the flow past a circular cylinder at cery high Reynolds number. J. Fluid Mech. 10(03): 345-356.

Sheppard, D., Odeh, M., and Glasser, T. 2004. Large scale clear-water local pier scour experiments. J. Hydraul. Eng. 130(10): 957-963.

Sheppard, D., Melville, B., and Demir, H. 2014. Evaluation of existing equations for local scour at bridge piers. J. Hydraul. Eng. 140(1): 14-23.

Tejada, S. 2014. Effects of blockage and relative coarseness on clear water bridge pier scour. M.A.Sc. thesis, Department of Civil and Environmental Engineering, University of Windsor, Windsor, ON.

Transportation Association of Canada. 2001. Guide to Bridge Hydraulics, $2^{\text {nd }}$ edition. ICE Publishing, UK.

Wardhana, K. and Hadipriono, F. 2003. Analysis of recent bridge failures in the United States. J. Perform. Constr. Fac. 17(3): 144-150. 
Williams, P., Balachandar, R., Bolisetti, T. 2013. Evaluation of local bridge pier scour depth estimation methods. In Proceedings of the 24th Canadian Congress of Applied Mechanics, Saskatoon, SK, Canada, 2-6 June 2013. Canadian Society of Mechanical Engineers, Ottawa, ON.

Table I: Experimental Work Plan

\begin{tabular}{|c|c|c|c|c|c|c|}
\hline $\begin{array}{c}\text { Test } \\
\text { ID }\end{array}$ & $\begin{array}{c}\mathbf{D} \\
\mathbf{( m )}\end{array}$ & $\begin{array}{c}\mathbf{d}_{\mathbf{5 0}} \\
\mathbf{( m m )}\end{array}$ & $\begin{array}{c}\mathbf{h} \\
\mathbf{( m )}\end{array}$ & $\begin{array}{c}\mathbf{b} \\
\mathbf{( m )}\end{array}$ & $\begin{array}{c}\mathbf{U} \\
(\mathbf{m} / \mathbf{s})\end{array}$ & $\mathbf{F r}$ \\
\hline A1 & 0.121 & 0.51 & 0.193 & 1.22 & 0.224 & 0.162 \\
A2 & $\mathrm{f}$ & 0.51 & 0.161 & 1.02 & 0.224 & 0.178 \\
A3 & 0.089 & 0.51 & 0.142 & 0.90 & 0.224 & 0.189 \\
A4 & 0.079 & 0.51 & 0.127 & 0.80 & 0.224 & 0.200 \\
A5 & 0.070 & 0.51 & 0.112 & 0.71 & 0.224 & 0.213 \\
A6 & 0.060 & 0.51 & 0.096 & 0.61 & 0.224 & 0.230 \\
& & & & & & \\
B1 & 0.121 & 0.77 & 0.193 & 1.22 & 0.259 & 0.188 \\
B2 & 0.101 & 0.77 & 0.161 & 1.02 & 0.259 & 0.206 \\
B3 & 0.089 & 0.77 & 0.142 & 0.90 & 0.259 & 0.219 \\
B4 & 0.079 & 0.77 & 0.127 & 0.80 & 0.259 & 0.232 \\
B5 & 0.070 & 0.77 & 0.112 & 0.71 & 0.259 & 0.247 \\
B6 & 0.060 & 0.77 & 0.096 & 0.61 & 0.259 & 0.266 \\
& & & & & & \\
E1 & 0.060 & 0.51 & 0.240 & 0.61 & 0.224 & 0.146 \\
E2 & 0.060 & 0.51 & 0.192 & 0.61 & 0.224 & 0.163 \\
E3 & 0.060 & 0.51 & 0.144 & 0.61 & 0.224 & 0.188 \\
E4 & 0.060 & 0.51 & 0.120 & 0.61 & 0.224 & 0.206 \\
E5 & 0.060 & 0.51 & 0.112 & 0.61 & 0.224 & 0.213 \\
E6 & 0.060 & 0.51 & 0.085 & 0.61 & 0.224 & 0.245 \\
& & & & & & \\
F1 & 0.060 & 0.77 & 0.241 & 0.61 & 0.259 & 0.168 \\
F2 & 0.060 & 0.77 & 0.193 & 0.61 & 0.259 & 0.188 \\
F3 & 0.060 & 0.77 & 0.142 & 0.61 & 0.259 & 0.217 \\
F4 & 0.060 & 0.77 & 0.120 & 0.61 & 0.259 & 0.239 \\
F5 & 0.060 & 0.77 & 0.096 & 0.61 & 0.259 & 0.266 \\
\hline & & & & & & \\
\hline
\end{tabular}


Table II: Experimental Results

\begin{tabular}{|c|c|c|c|c|}
\hline $\begin{array}{l}\text { Test } \\
\text { ID }\end{array}$ & $\begin{array}{c}\mathbf{d}_{\mathrm{se}} \\
(\mathbf{m m})\end{array}$ & $\mathbf{d}_{\mathrm{se}} / \mathbf{D}$ & $\begin{array}{c}\mathbf{W}_{\mathbf{s}} \\
(\mathbf{m m})\end{array}$ & $\mathbf{w}_{\mathrm{s}} / \mathbf{D}$ \\
\hline A1 & 90.6 & 0.751 & 494 & 4.09 \\
\hline A2 & 71.2 & 0.706 & 414 & 4.11 \\
\hline A3 & 67.3 & 0.757 & 367 & 4.13 \\
\hline A4 & 64.3 & 0.810 & 327 & 4.12 \\
\hline A5 & 62.3 & 0.892 & 322 & 4.61 \\
\hline A6 & 58.7 & 0.974 & 294 & 4.88 \\
\hline B1 & 75.1 & 0.622 & 434 & 3.60 \\
\hline B2 & 81.8 & 0.812 & 435 & 4.32 \\
\hline B3 & 72.6 & 0.817 & 379 & 4.26 \\
\hline B4 & 70.0 & 0.882 & 354 & 4.46 \\
\hline B5 & 62.9 & 0.901 & 329 & 4.71 \\
\hline B6 & 57.0 & 0.946 & 266 & 4.41 \\
\hline E1 & 8.75 & 1.452 & 42.3 & 7.02 \\
\hline E2 & 9.56 & 1.587 & 48.0 & 7.97 \\
\hline E3 & 10.23 & 1.698 & 48.4 & 8.03 \\
\hline E4 & 10.08 & 1.673 & 44.0 & 7.30 \\
\hline E5 & 8.40 & 1.394 & 39.0 & 6.47 \\
\hline E6 & 7.21 & 1.197 & 34.2 & 5.68 \\
\hline $\mathrm{F} 1$ & 7.57 & 1.256 & 32.4 & 5.38 \\
\hline F2 & 9.78 & 1.623 & f44.6 & 7.40 \\
\hline F3 & 9.33 & 1.549 & 43.0 & 7.14 \\
\hline F4 & 9.55 & 1.585 & 40.8 & 6.77 \\
\hline F5 & 5.70 & 0.946 & 26.6 & 4.41 \\
\hline
\end{tabular}




\section{LIST OF SYMBOLS}

\begin{tabular}{|c|c|}
\hline$a^{*}$ & effective pier diameter (Froehlich equation, Sheppard-Melville equation) \\
\hline Al & pier alignment factor \\
\hline ASTM & American Society for Testing and Materials \\
\hline $\mathrm{b}$ & flume or channel width \\
\hline $\mathrm{D}$ & pier width \\
\hline $\mathrm{D} / \mathrm{b}$ & blockage ratio \\
\hline $\mathrm{D} / \mathrm{d}_{50}$ & relative coarseness \\
\hline $\mathrm{d}_{50}$ & median sediment diameter \\
\hline $\mathrm{d}_{\mathrm{se}}$ & equilibrium scour depth \\
\hline $\mathrm{d}_{\mathrm{se}} / \mathrm{D}$ & relative scour depth \\
\hline$d_{x}$ & sediment size of which subscript " $\mathrm{x}$ " percent is finer by weight \\
\hline $\mathrm{Eu}$ & Euler number \\
\hline $\mathrm{Eu}_{\mathrm{d}}$ & Pier Euler number \\
\hline $\mathrm{F}_{\mathrm{d}}$ & densimetric Froude number \\
\hline $\mathrm{F}_{\mathrm{ds}}$ & densimetric Froude number based on separation velocity \\
\hline $\mathrm{Fr}$ & Froude number \\
\hline $\mathrm{Fr}_{\mathrm{c}}$ & critical Froude number \\
\hline $\mathrm{Fr}_{\mathrm{s}}$ & Froude number based on separation velocity \\
\hline $\mathrm{g}$ & gravitational acceleration \\
\hline $\mathrm{h}$ & approach flow depth \\
\hline $\mathrm{h} / \mathrm{D}$ & flow shallowness \\
\hline $\mathrm{K}_{1}$ & flow intensity parameter (Melville and Sutherland equation) \\
\hline $\mathrm{K}_{1}$ & pier nose shape factor (HEC-18 equation) \\
\hline $\mathrm{K}_{2}$ & angle of attack factor (HEC-18 equation) \\
\hline $\mathrm{K}_{3}$ & bed condition factor (HEC-18 equation) \\
\hline $\mathrm{K}_{4}$ & armoring condition factor (HEC-18 equation) \\
\hline $\mathrm{K}_{\mathrm{d}}$ & sediment size parameter (Melville and Sutherland equation) \\
\hline $\mathrm{K}_{\mathrm{s}}$ & pier shape parameter (Melville and Sutherland equation) \\
\hline $\mathrm{K}_{\mathrm{y}}$ & flow depth parameter (Melville and Sutherland equation) \\
\hline $\mathrm{K}_{\alpha}$ & pier alignment parameter (Melville and Sutherland equation) \\
\hline $\mathrm{K}_{\sigma}$ & sediment gradation parameter (Melville and Sutherland equation) \\
\hline Q & flow rate \\
\hline $\operatorname{Re}$ & Reynolds number \\
\hline SG & specific gravity \\
\hline $\mathrm{Sh}$ & pier shape factor \\
\hline
\end{tabular}




$\begin{array}{ll}\mathrm{St} & \text { Strouhal number } \\ \mathrm{t}_{\mathrm{s}} & \text { time to scour } \\ \mathrm{t}_{\mathrm{se}} & \text { time to equilibrium scour } \\ \mathrm{U} & \text { mean approach flow velocity } \\ \mathrm{U} / \mathrm{U}_{\mathrm{c}} & \text { flow intensity } \\ \mathrm{U}_{\mathrm{c}} & \text { critical velocity of bed material } \\ \mathrm{U}_{\mathrm{s}} & \text { velocity along streamline at point of separation on pier } \\ \mathrm{w}_{\mathrm{s}} & \text { width of scour hole } \\ \mathrm{w}_{\mathrm{S}} / \mathrm{D} & \text { relative scour width } \\ \mathrm{x} & \text { direction of flow } \\ \mathrm{y} & \text { direction transverse to the flow } \\ \mathrm{z} & \text { vertical direction normal to the xy plane } \\ \Theta & \text { angle of attack of approach flow } \\ \lambda & \text { scale factor } \\ \mu & \text { fluid dynamic viscosity } \\ v & \text { fluid kinematic viscosity } \\ \rho & \text { fluid density } \\ \rho_{\mathrm{s}} & \text { sediment density } \\ \sigma_{\mathrm{g}} & \text { uniformity of particle size distribution } \\ \varphi & \text { pier nose shape factor (Froehlich equation) }\end{array}$




\section{List of Figures}

Figure 1: Experimental set-up

Figure 2: Centreline and contour profiles for series A $(a, c)$ and series B tests $(b, d)(h / D=1.6$, $\left.\mathrm{U} / \mathrm{U}_{\mathrm{c}}=0.85\right)$

Figure 3: Variation of $d_{s e} / D$ and $w_{s} / D$ with relative coarseness for phase $I$ (constant $h / D$ and $\left.\mathrm{U} / \mathrm{U}_{\mathrm{c}}\right)$

Figure 4: Comparison of centreline and contour profiles for phase I: A6/B3 (a,d), A5/B2 (b,e), A4/B1 (c,f)

Figure 5: Centreline and contour profiles for series $E(a, c)$ and series $F$ tests $(b, d)(U / U c=0.85)$

Figure 6: Variation of $\mathrm{d}_{\mathrm{se}} / \mathrm{D}$ and $\mathrm{w}_{\mathrm{s}} / \mathrm{D}$ with flow shallowness for series $\mathrm{E}$ and series $\mathrm{F}$ (constant $\left.\mathrm{U} / \mathrm{U}_{\mathrm{c}}\right)$

Figure 7: Comparison of centreline and contour profiles for phase II: E4/F4 (a,d), E3/F3 (b,e), $\mathrm{E} 2 / \mathrm{F} 2(\mathrm{c}, \mathrm{f})$

Figure 8: Variation of University of Windsor results and Ettema et al. (2006) compared with a) $\mathrm{D} / \mathrm{d}_{50}$ and b) $\mathrm{D} / \mathrm{d}_{50}$ grouped by $\mathrm{F}_{\mathrm{d}}$

Figure 9: Measured vs. predicted values of $d_{\text {se }} / D$ for various investigations using Equation 8 


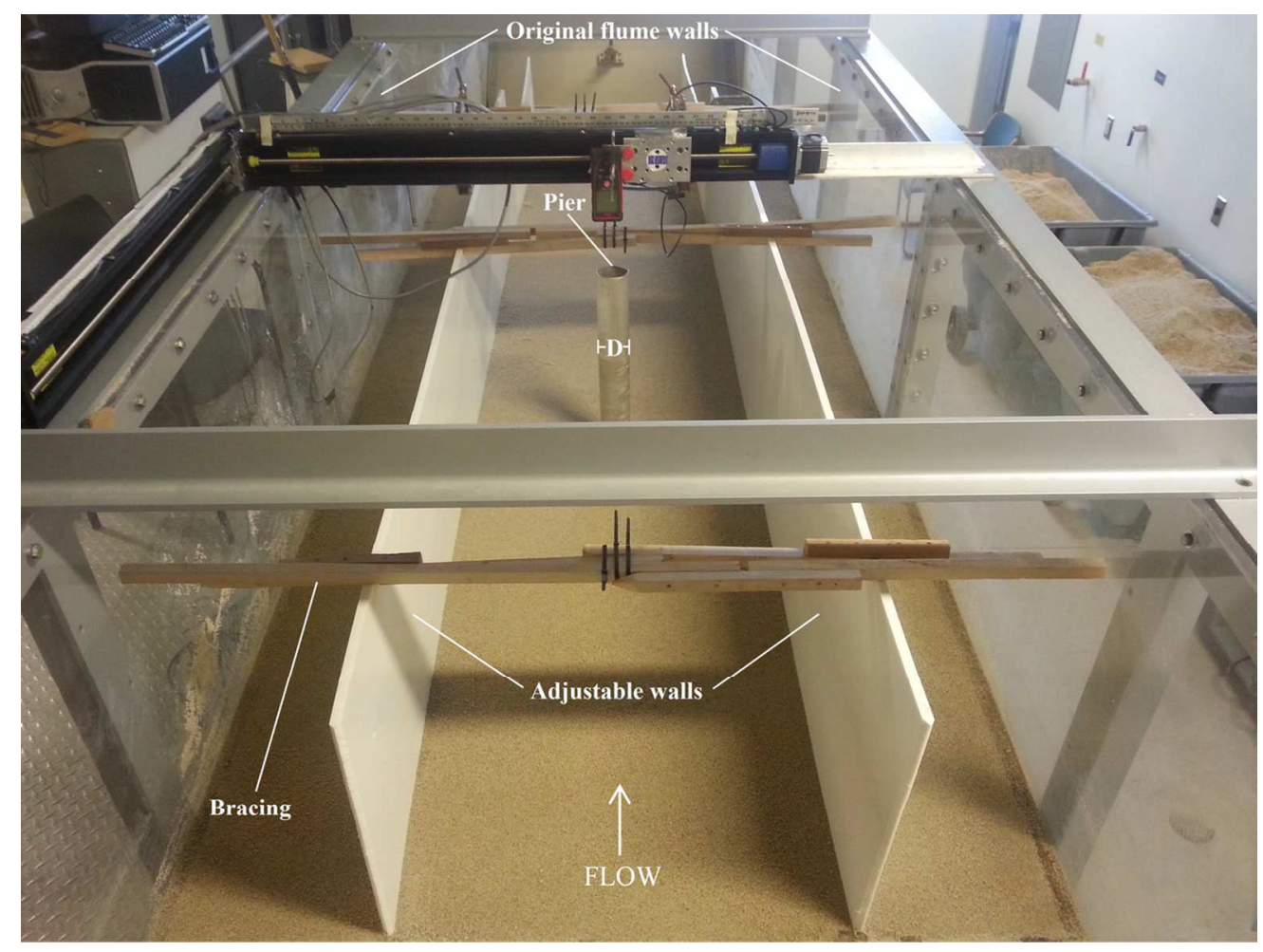

Figure 1: Experimental set-up $118 \times 88 \mathrm{~mm}(300 \times 300 \mathrm{DPI})$ 
$d_{50}=0.51 \mathrm{~mm}, \mathrm{~h} / \mathrm{D}=1.6, \mathrm{D} / \mathrm{b}=10 \%, \mathrm{U} / \mathrm{U}_{\mathrm{c}}=0.85$

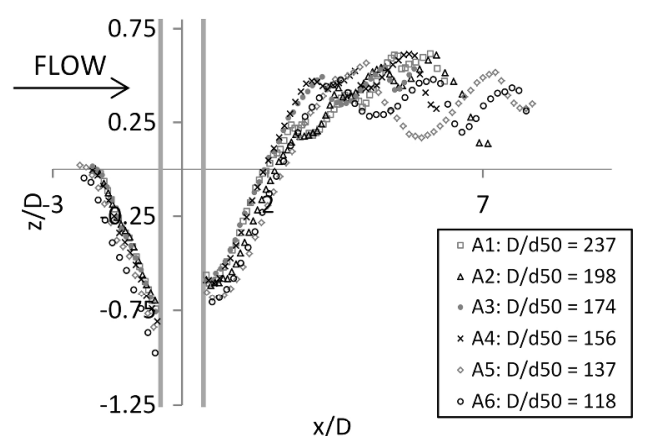

(a)

$d_{50}=0.77 \mathrm{~mm}, \mathrm{~h} / \mathrm{D}=1.6, \mathrm{D} / \mathrm{b}=10 \%, \mathrm{U} / \mathrm{U}_{\mathrm{c}}=0.85$

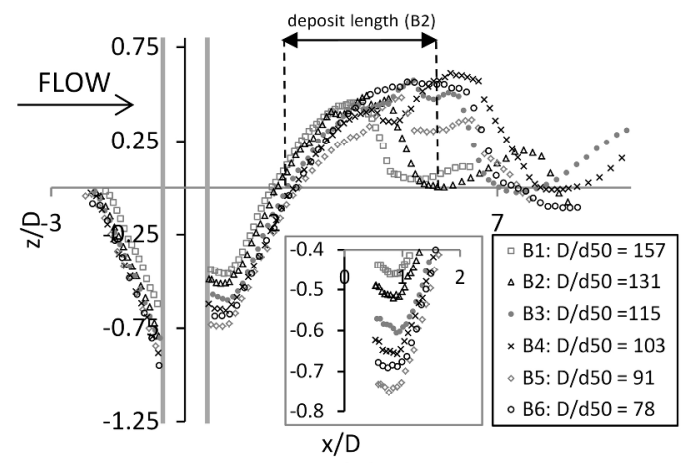

(b)

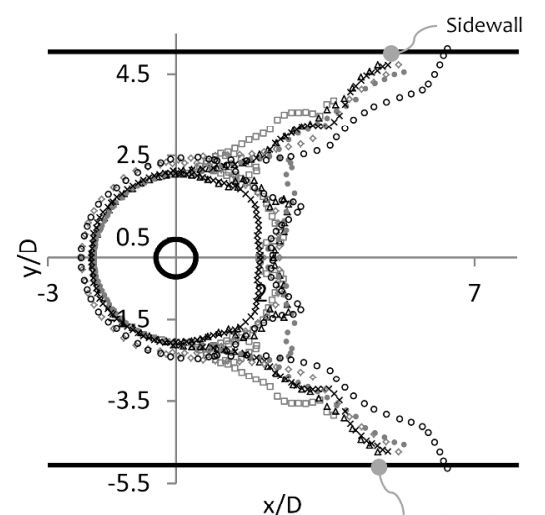

(c)

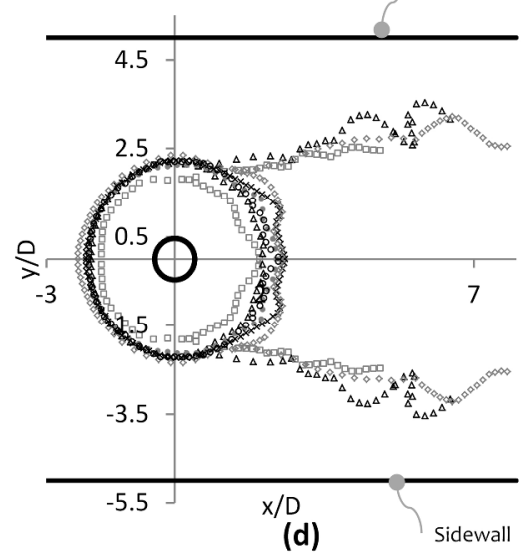

Figure 2: Centreline and contour profiles for series $A(a, c)$ and series $B$ tests $(b, d)(h / D=1.6, U / U c=0.85)$ $143 \times 124 \mathrm{~mm}(600 \times 600 \mathrm{DPI})$ 


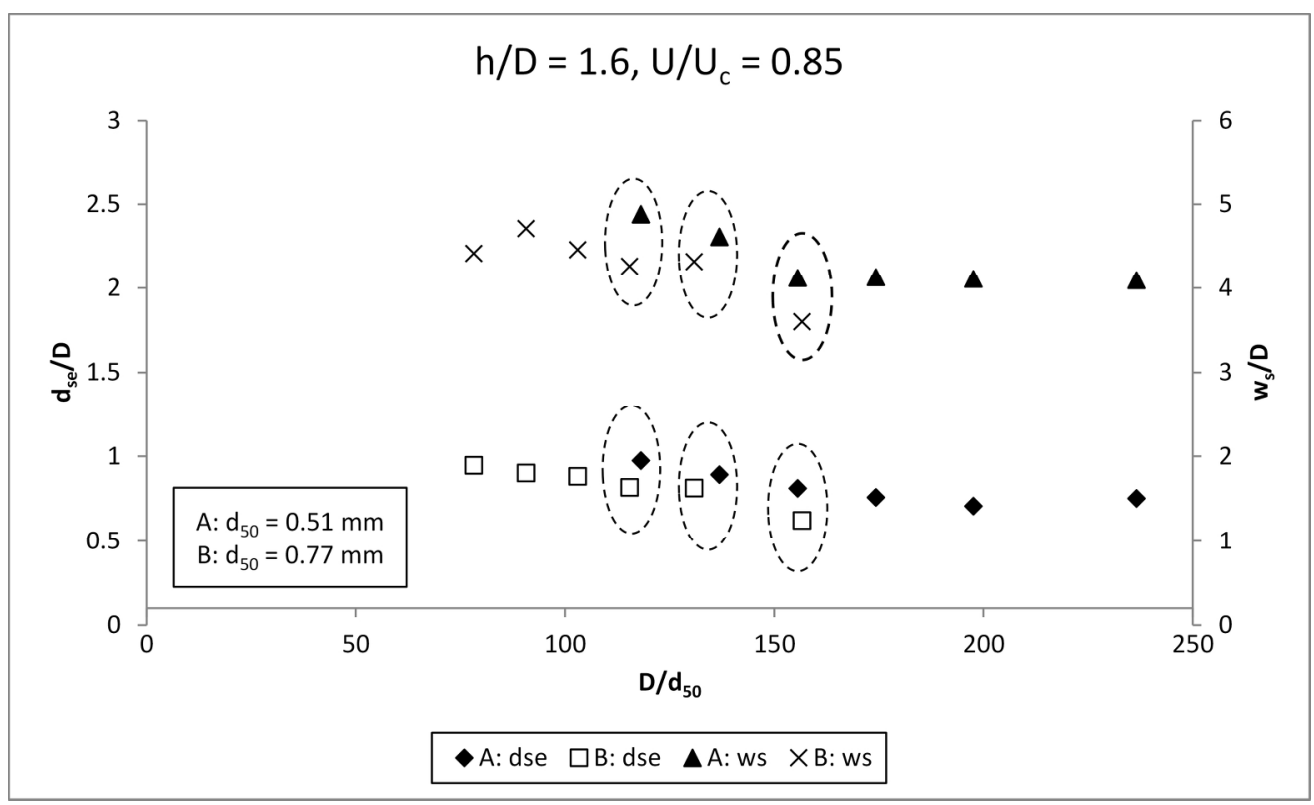

Figure 3: Variation of dse/D and ws/D with relative coarseness for phase I (constant $h / D$ and $U / U c$ ) $99 \times 60 \mathrm{~mm}(600 \times 600 \mathrm{DPI})$ 


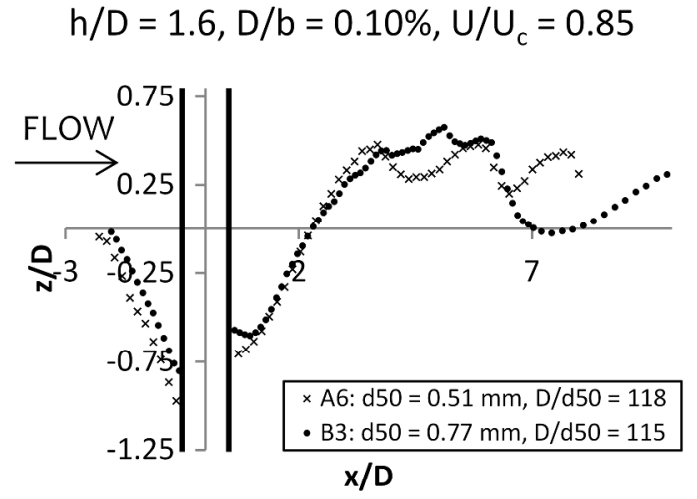

(a)

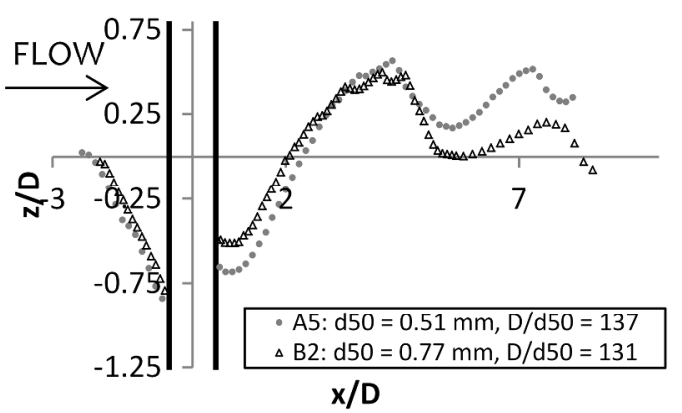

(b)

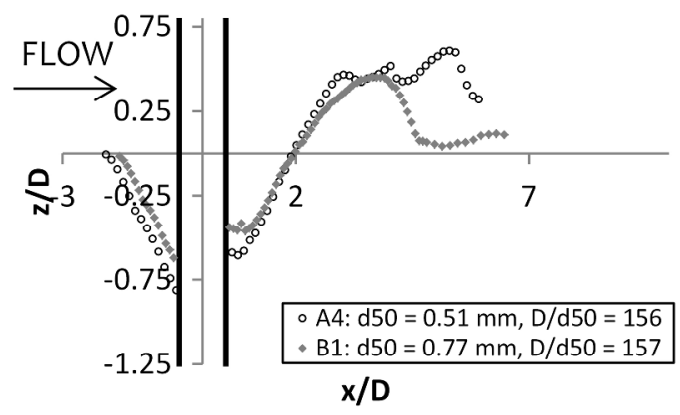

(c)

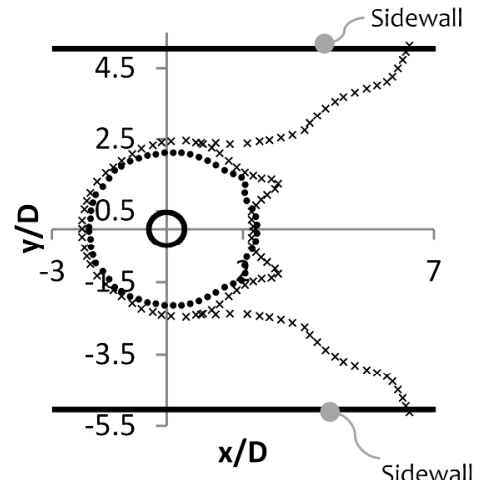

(d)

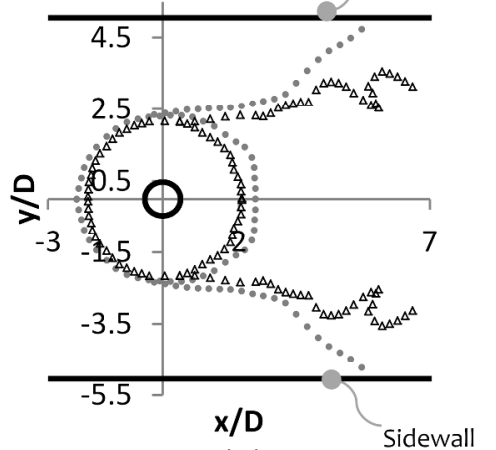

(e)

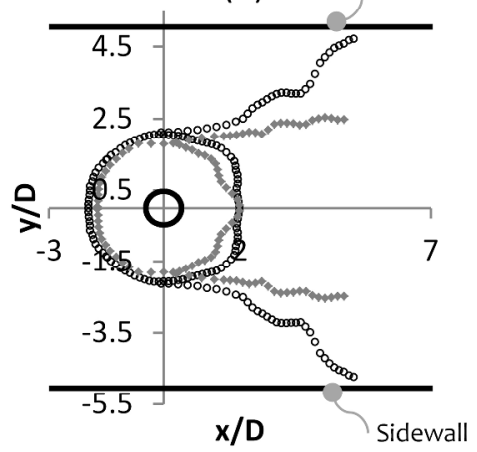

(f)

Figure 4: Comparison of centreline and contour profiles for phase I: A6/B3 (a,d), A5/B2 (b,e), A4/B1 (c,f) $159 \times 188 \mathrm{~mm}(600 \times 600 \mathrm{DPI})$ 
$\mathrm{d}_{50}=0.51 \mathrm{~mm}, \mathrm{D} / \mathrm{d}_{50}=118, \mathrm{D} / \mathrm{b}=10 \%, \mathrm{U} / \mathrm{U}_{\mathrm{c}}=0.85$

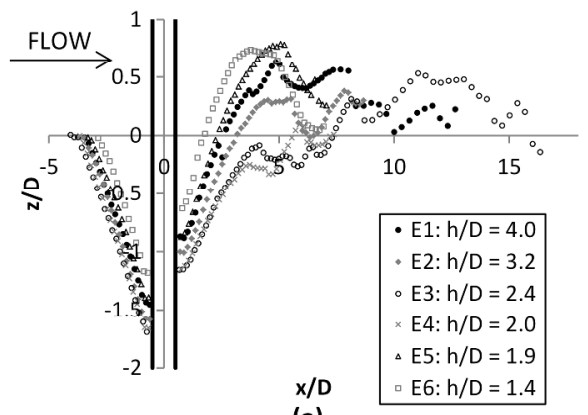

(a)

$\mathrm{d}_{50}=0.77 \mathrm{~mm}, \mathrm{D} / \mathrm{d}_{50}=78, \mathrm{D} / \mathrm{b}=10 \%, \mathrm{U} / \mathrm{U}_{\mathrm{c}}=0.85$

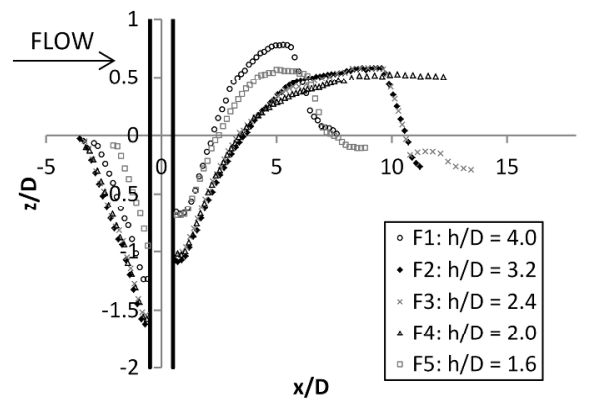

(b)

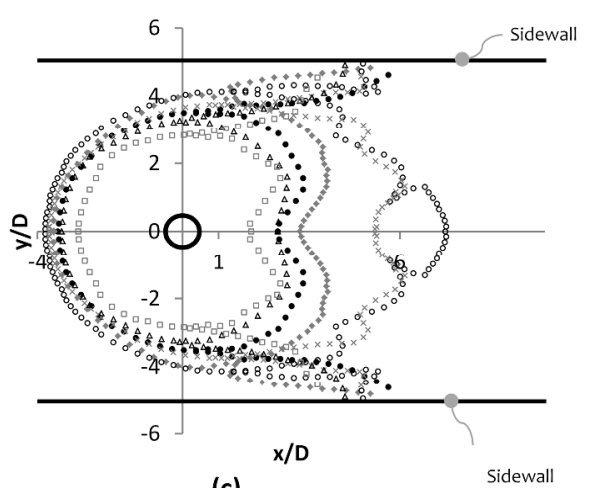

(c)

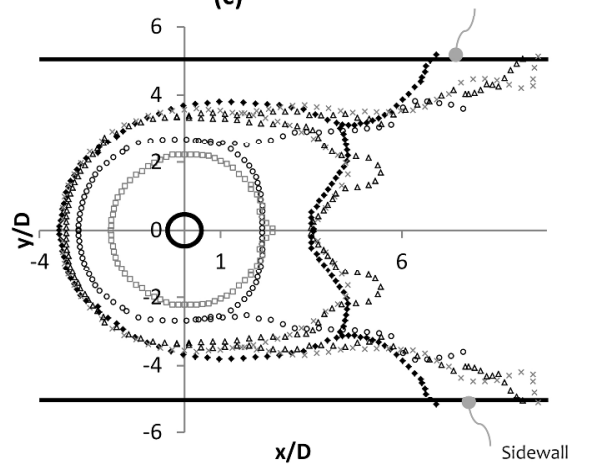

(d)

Figure 5: Centreline and contour profiles for series $E(a, c)$ and series $F$ tests $(b, d)(U / U c=0.85)$ $144 \times 112 \mathrm{~mm}(600 \times 600 \mathrm{DPI})$ 


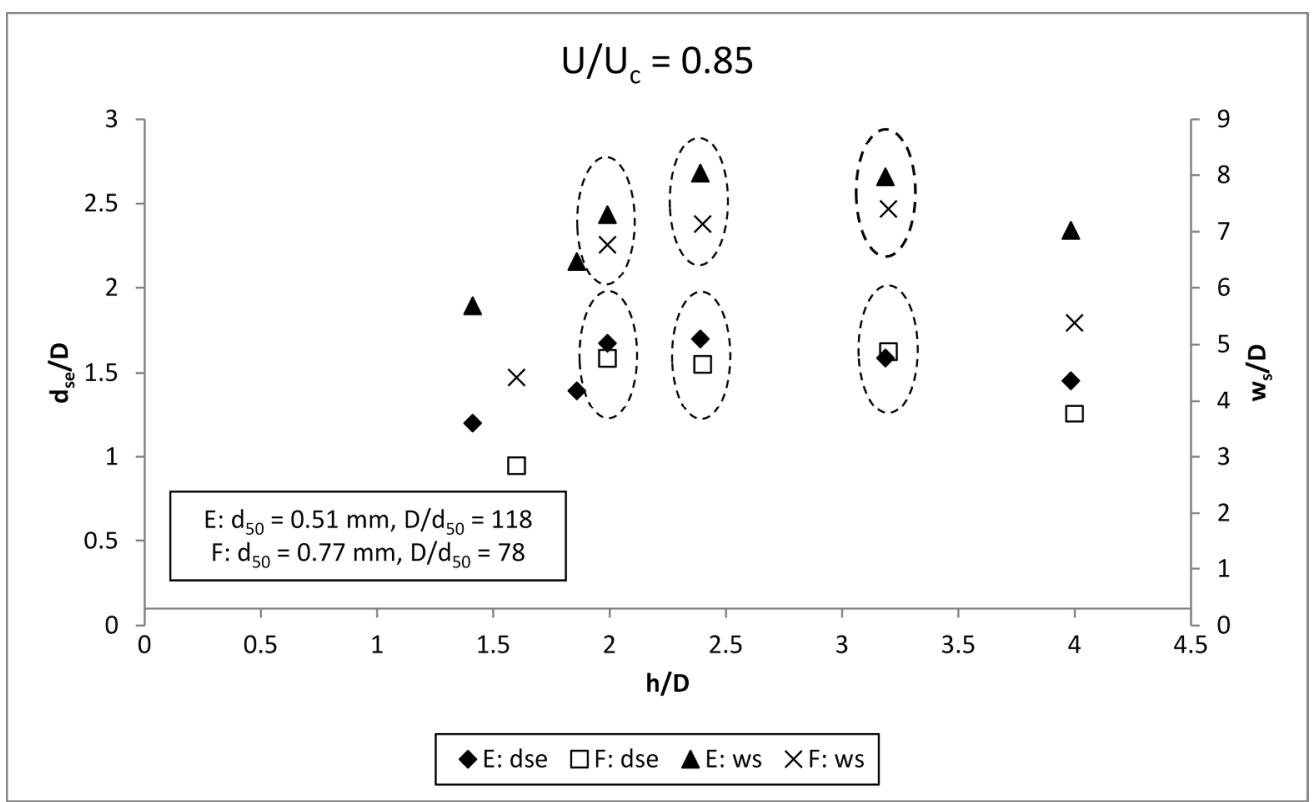

Figure 6: Variation of dse/D and ws/D with flow shallowness for series $E$ and series $F$ (constant U/UC) $99 \times 60 \mathrm{~mm}(600 \times 600 \mathrm{DPI})$ 


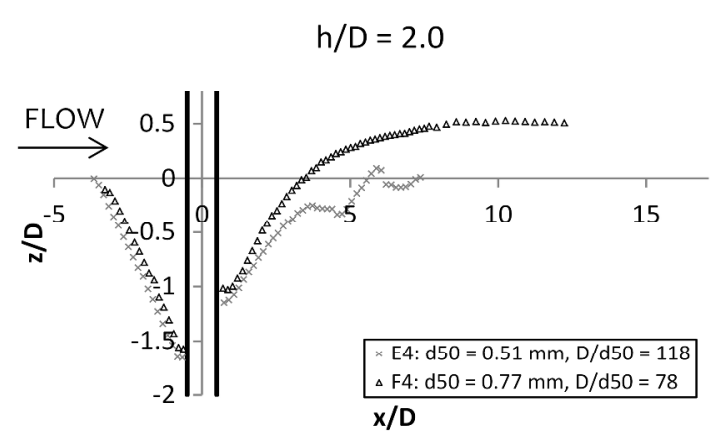

(a)

$h / D=2.4$

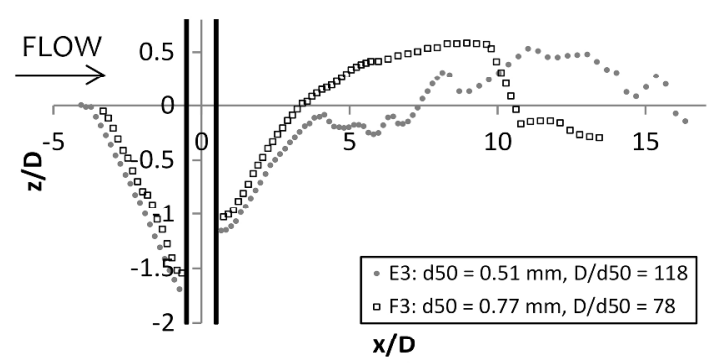

(b)

$h / D=3.2$

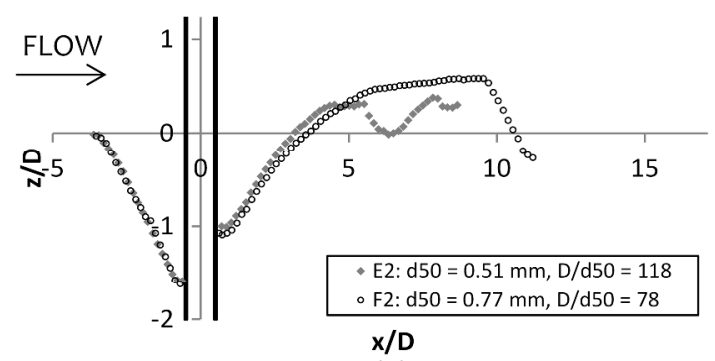

(c)

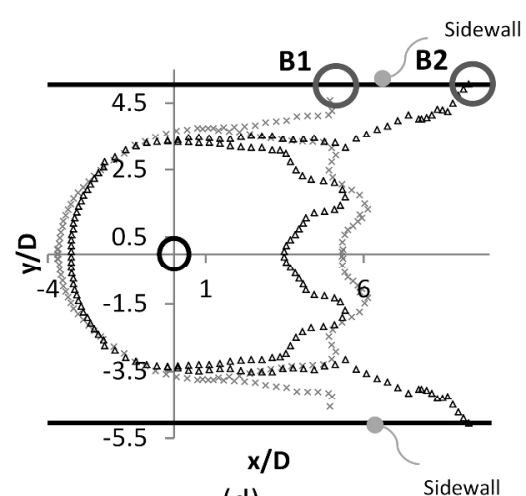

(d) B1

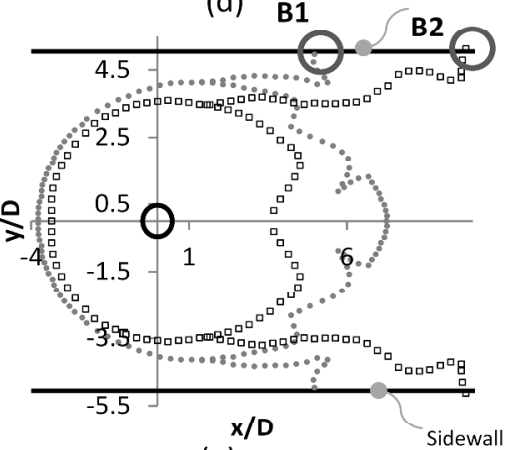

(e)

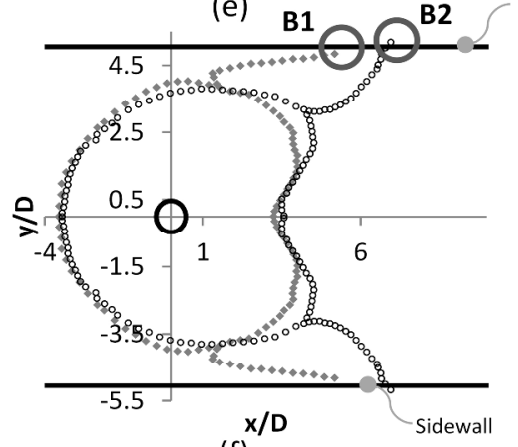

(f)

Figure 7: Comparison of centreline and contour profiles for phase II: E4/F4 (a,d), E3/F3 (b,e), E2/F2 (c,f) $177 \times 196 \mathrm{~mm}(600 \times 600 \mathrm{DPI})$ 
(a) $D / d_{50}$ vs. $d_{\text {se }} / D$

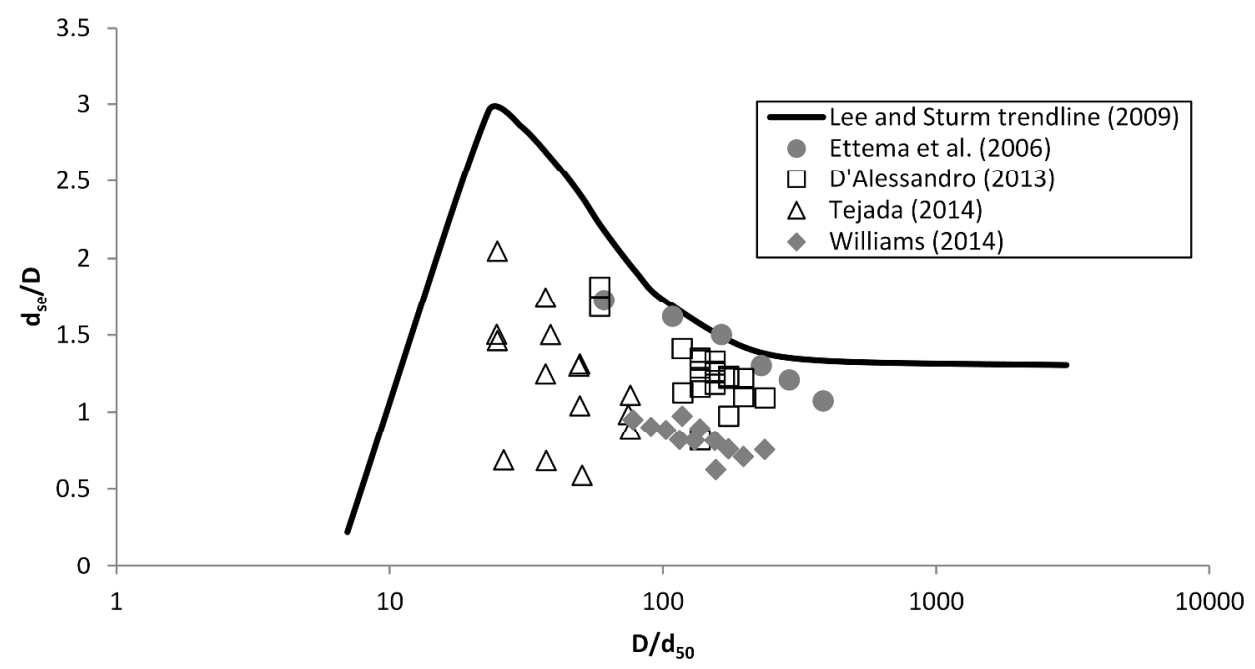

(b) $D / d_{50}$ vs. $d_{s e} / D$

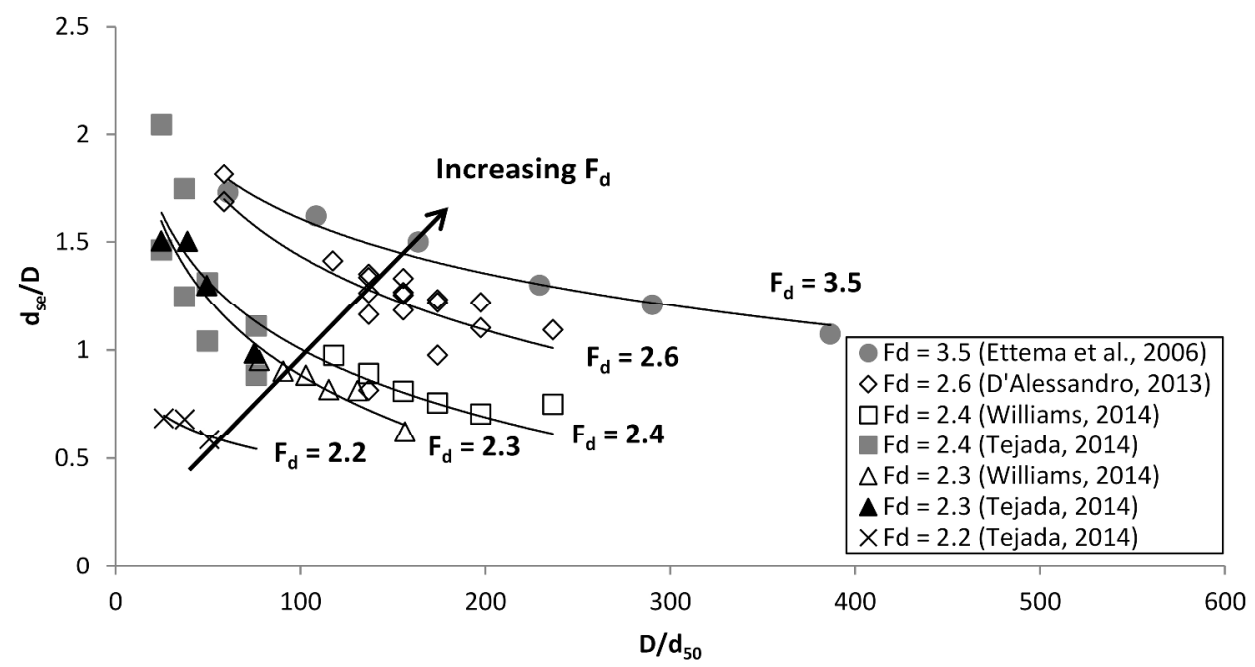

Figure 8: Variation of University of Windsor results and Ettema et al. (2006) compared with a) D/d50 and b) $\mathrm{D} / \mathrm{d} 50$ grouped by $\mathrm{Fd}$

$198 \times 239 \mathrm{~mm}(600 \times 600 \mathrm{DPI})$ 

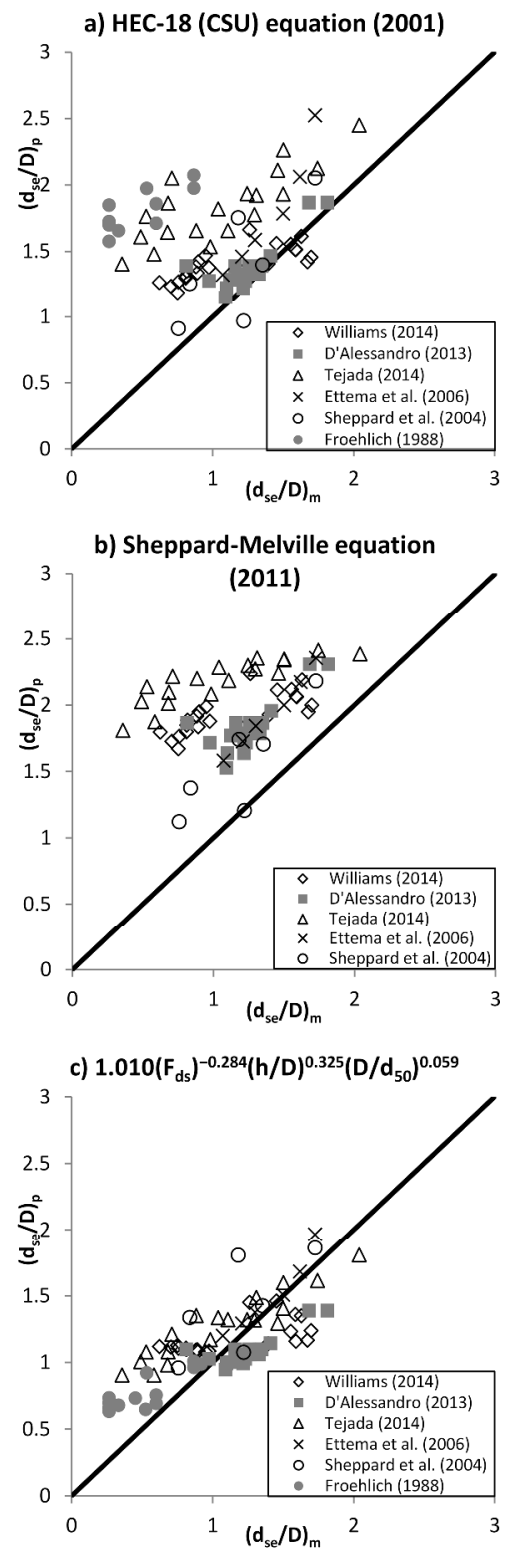

Figure 9: Measured vs. predicted values of dse/D for various investigations using Equation 8 $244 \times 747 m m(600 \times 600$ DPI $)$ 